San Jose State University

From the SelectedWorks of Anne Fountain

December 19, 2019

\title{
José Martí: The World's Most Popular Poetry, and a Vision for the Americas
}

Anne O Fountain, San Jose State University 


\title{
José Martí
}

\section{The World's Most Popular Poetry, and a Vision for the Americas}

\author{
Anne Fountain \\ San José State University, USA
}

José Martí (1853-1895) defies easy categorization. He was a patriot who became Cuba's national hero, a poet who anticipated the revival of letters in the Spanish-speaking world known in Spanish as modernismo, a prolific and influential essayist, a translator fluent in Spanish, French, and English, an author of exquisite children's literature, a creator of verses that have become world famous, a pioneer in race relations, a landmark figure in Cuban-US relations, and a literary bridge between the United States and Latin America. He is at once the most universal Cuban and the island's most closely held and cherished native son, and his work embraces both the nineteenth century of his lifetime and, through his legacy, the twentieth and twenty-first centuries as well.

Because Martî's versatility and impact are remarkable, brief introductions to his life and writing will help set the stage for the focus of this chapter, the two works that have resonated most broadly across public and academic spheres: Simple Verses (Versos Sencillos), the book of 46 poems he published in 1891, and the iconic essay "Our America" ("Nuestra América"), also from 1891. Martî's writing covered a wide range of genres and topics. His essays, poetry, translations, letters, oratory, and notebook comments are collected in the 26 volumes of his writings, published in the 1963-1973 Cuban edition of the complete works.

A Companion to World Literature. Edited by Ken Seigneurie.

๑) 2019 John Wiley \& Sons, Ltd. Published 2019 by John Wiley \& Sons, Ltd.

DOI: 10.1002/9781118635193.ctwl0217 


\section{Biographical Overview and Literary Fame}

Born in Cuba when it was still a slave-holding colony of Spain, Martí from a tender age championed independence for the island and an end to the enslavement of Africans. Exile took him to Europe, to Mexico and Central America, and to Venezuela, and he spent the last fourteen and a half years of his life in the United States, where he produced the major part of his vast literary work. In New York, his primary domicile during his US residence (1881-1895), he became a journalist sending chronicles about American life in all its facets to major Spanish American newspapers. These chronicles, crónicas, as they are known in Spanish, became a signature example of Martî's style. They blended accounts of news, absorbed in the main from US newspapers and journals, with essayistic comments that resulted in pieces of literary quality. The Cuban exile also constantly worked to advance the decolonization of his homeland by countering propaganda by Spain that promoted fears of racial tension, and insisting that Cuba should be free of US interference. His powerful oratory delivered with cascading rhythms to audiences of both black and white Cubans who were living in the United States called for unity and racial harmony as the island sought its independence.

The year 1891 marked a transition in Martî́s labors. From this point on, his primary focus was on writing, speaking, and organizing on behalf of the Cuban Revolutionary Party and its goals for a military uprising that would oust the Spanish. In 1895, he traveled to his homeland to join the insurrection against Spanish rule and on 19 May was felled by enemy fire near Dos Ríos in the eastern part of Cuba. In death, he became a heroic symbol of nobility of purpose and the Cuban desire for freedom.

Martí is known in literary circles chiefly for his poetry and his essays, especially the chronicles. His many volumes of articles about North American life in the 1880s and early 1890s describe Gilded Age extravagance along with scenes of poverty and suffering. He attacked social injustice on diverse fronts: Indians pushed from their tribal lands, immigrants from Europe and Asia scorned by the ruling Anglo classes, horrific violence, including lynchings, faced by Southern blacks in the post-Reconstruction era, and afflictions endured by workers who toiled for unfair wages. In addition, he entered fully into the nation's cultural milieu, writing extensively about American authors, from literary giants like Emerson, Whitman, and Longfellow to writers of the Romantic movement and those known for realism, like Mark Twain and Helen Hunt Jackson. His style in the chronicles was unmistakable. He combined long, complex narrations with capsule declarations that elegantly summarized a topic, and his distinctive aphorisms revealed truths about race, character, and social justice. His articles were often intense and dramatic yet dioramic in scope. In many instances, he translated and quoted from US sources in English. Martí's concise statements in the chronicles often hewed closely to his beliefs. In an article that criticized gross inequality he wrote: "when one man sleeps in the muck, by what right does another get to sleep in a bed of gold?" $(10,146),{ }^{1}$ and continued by declaring: "To be charitable one must have been unfortunate" (10, 147). From Emerson Martí translated into Spanish the maxim: "To be great is to be misunderstood" $(13,30)$.

In addition to the essays, Martí is best known for poetry, especially from the books Ismaelillo (Little Ishmael), tender verses dedicated to his son, published in 1882, and Simple Verses of 1891, the sincere verses that sprang from the heart and reflected defining moments 
of his life and sentiments that he held dear. The surprising images he created in Ismaelillo are the stirrings of modernismo, a renaissance in Hispanic letters that is closely associated with the Nicaraguan poet Rubén Darío (see Rubén Darío and the Nymph of France). Two other books of poetry, Versos libres (Free verses) and Flores del destierro (Flowers from exile), were published posthumously.

No account of Martîs significance in literature is complete without mention of the four issues of the magazine La Edad de Oro (The Golden Age) that he published in 1889. The stories, fables, and poetry of this collection, which includes a translation of Emerson's "Fable," and a poem known to every Cuban child, "Los zapaticos de rosa" (The rose-colored slippers), are among the most beloved pieces of literature for children in the Spanish language. La Edad de Oro contains moral messages that underscore equality and dignity for all: rich or poor, great or small. The work also highlights the courage and strength of character of Latin American champions of independence: Simón Bolívar, José de San Martín, and Father Miguel Hidalgo.

\section{Transcultural Impact}

José Martî́s impressive success as a translator is an often overlooked part of his literary profile. He translated Victor Hugo's Mes Fils (My sons) (see Victor Hugo's Romantic Registers) from French to Spanish and published the Spanish version in Mexico in 1875. During his long tenure in the United States, he undertook translation contract work and, more importantly, made translation a fundamental part of the composition of his chronicles. Gleaning material from US newspapers and journals, he absorbed stories and news reports and recast them, sometimes in beautifully rendered translations and often in paraphrases mixed with commentary that reflected his own opinions. In 1888, he published a slightly shortened translation into Spanish of Helen Hunt Jackson's novel Ramona, with the goal of warning Mexicans about the Hispanic experience in California, the plight of the Indians, and the perils of Anglo domination. Martí saw the novel's love story as an appealing feature that would draw readers into the larger canvas of nineteenth-century California history after the Mexican-American War (1846-1848), when Mexicans and Indians faced displacement by white settlers.

In addition, José Martí played a pivotal role in introducing US authors to South American audiences. His profound admiration for Ralph Waldo Emerson led to an engagement with the American writer over many years, and his lengthy essay about Emerson sent to La Opinión Nacional (The national opinion) of Caracas in 1882 circulated in Spanish America long afterward. The essay presented a glowing appraisal of the American author, with numerous quotes from Emerson translated masterfully by Martí into Spanish. Martîs notebooks included translated portions of several poems by the American transcendentalist, and some of those translations served as inspiration for Martîs own poetry in Simple Verses. Martí was also responsible for bringing Walt Whitman (see Walt Whitman "Over the Roofs of the World") to the attention of Spanish Americans. His 1887 report following Whitman's Lincoln Lecture in New York and sent to leading newspapers in Mexico and Argentina championed Whitman's revolutionary voice and featured over 50 translations, paraphrases, and direct references to Whitman's works, especially from Leaves of Grass. 
Marti, living in exile in the United States, saw warning signs of imperialistic intent directed toward Spanish America and worried especially about US designs on Cuba. He challenged the condescension and racism that pervaded much of the commentary when North Americans wrote about their southern neighbors, and in March 1889 he forcefully defended Cuban integrity in a letter to the New York Evening Post that is now known by the title "Vindication of Cuba." In this letter, written in English, Martí responded to articles published by the Pbiladelphia Manufacturer and the New York Evening Post that rejected the idea that the United States should seek to acquire Cuba from Spain. Using slanderous language, the newspapers criticized the ethnic makeup of Cuba, especially its black population, and declared that Cuba was not worthy of affiliation with the United States. Through the vigorous language of "Vindication of Cuba," in works like "Our America," and in the prologue to Simple Verses, Martí became a principal voice concerning US-Cuban relations and the need for Cubans and their desire for independence to be respected.

José Martí did not live to see the results of the Spanish-Cuban-American War of 1898. However, with the end of Spain's colonial rule and Cuba's occupation by US forces, some of Martî's fears about imperialist intent were realized. When the Cuban Republic was established in 1902, the United States insisted that the Platt Amendment, giving the powerful neighbor the right to intervene in Cuban affairs, be part of the Cuban constitution. Although the amendment was finally abrogated in 1934, its imposition represented the kind of condescension on the part of the United States that Martí had argued against in his writing.

In 1959, the Cuban Revolution led by Fidel Castro signaled a dramatic change in US-Cuba relations, and under the communist government Martî́s words took on a prominent role. The Castro government embraced Martí as a standard bearer for its aims and made his works, especially his anti-imperialist messages directed at the United States, a key part of Cuban education and daily life. Aphorisms created by Martí in the nineteenth century became part of post-1959 billboards and murals throughout the island. A line from "Our America" exemplified the tone of messages that emphasized sacrifice and cultural independence: "The wine made from bananas may be bitter, but it's our wine!" $(6,20)$. A declaration from his journal, Patria (Homeland), rallied patriotic instincts with the succinct claim: "Homeland means humanity" (5, 468). From exile, Cubans who had fled the Castro regime presented the same Martí as one of their own, pointing to the national hero's lifelong passion for liberty, his appreciation of freedom of the press, and his praise for numerous aspects of US life. With few exceptions, Cubans living abroad portrayed Martís ideals as intrinsically antithetical to the authoritarian regime.

\section{Marti’s Global Reach in the Twenty-First Century}

That a writer born in colonial Cuba could speak so clearly to the postcolonial world of the twentieth and twenty-first centuries is one of the remarkable aspects of Martís life and work. His experiences as an exile, exposure to imperialist threats, ability to analyze history, suggest solutions, and connect with the common man are part of the explanation. In addition, cultural and societal contexts have influenced the dissemination of his writing. Two works, Simple Verses and "Our America" illustrate the global reach. Stanzas from Simple 
Verses are sung around the world through the music of Guantanamera, and "Our America" has become a key point of reference for scholarship about Martí, Cuba, and inter-American relations.

The poems in Simple Verses were composed in the Catskill Mountains of New York in the summer of 1890, where Martí was resting and recuperating on doctor's orders. Part of the stress that precipitated the doctor's decree was the Pan-American Conference held in Washington, DC, an event Martí described in anguished terms in the prologue to the poems. Conference sessions began in October 1889 and ended in April 1890, and Martí followed the trajectory closely, sending detailed articles about conference activities to the Buenos Aires newspaper La Nación (The nation). The conference was orchestrated by US secretary of state James G. Blaine for the ostensible purpose of fostering inter-American understanding and addressing issues like a customs union, but that also included a sub-rosa plan to acquire Cuba from Spain. For Martí, the specter of his beloved homeland possibly falling under the control of the northern Colossus was profoundly disheartening, even though Blaine's Cuba plans were never realized.

In the restful setting of the Catskills, Martís patriotic and personal themes merged in the composition of verses published in the following year. In December 1890, he shared his poetry in a reading before friends. When the slender volume of 46 poems went to press in New York in August of 1891, the author's prologue made note of both his "winter of anguish" due to the Washington conference and his "evening of poetry and friendship" that had already made the verses public. Simple Verses carried Martîs preoccupation with North America's imperialistic gaze toward Latin America but also reflected the support and consolation of friendship. The published work included a dedication to two important friends, Manuel Mercado of Mexico and Enrique Estrázulas of Uruguay.

The topics covered in Simple Verses are varied, but many are autobiographical. They include Martî's sobering remembrance of slavery in Cuba in poem XXX (the poems are not named) of Simple Verses. In five succinct stanzas Martí recounts what he witnessed in the Cuban countryside as a nine-year-old. Africans are unloaded from a ship, marched naked to the crack of a whip, crowded into wretched barracks and find death as the only escape from suffering. At the end of the poem, the boy promises at the foot of a slave who has hanged himself to redress the crime $(16,106-107)$. Poem number I of the book opens with lines that are now widely known: "I am a sincere man / Born where palm trees grow" ("Yo soy un hombre sincero / De donde crece la palma"). While many poems in Simple Verses begin in first-person mode, Martîs "I" is not a selfish claim but rather an introduction to universal concerns: love, friendship, loyalty, and respect for nature. The book also asserts key precepts about the importance of sacrifice and solidarity such as Martî's claim in poem $\mathrm{XXV}$ that his grave will require nothing more than flowers and a flag and his statement in poem III that he is casting his lot with the poor of the world.

Simple Verses is noted for chromatism and contrasts that reflect the dual moods described in the prologue. One of the best-known poems, number XXXIX, exemplifies the use of color and contrasts. The original lines as given in English translation are followed by the poem in Spanish:

I cultivate a white rose,

In July and in January,

For the sincere friend 
Who offers his honest hand.

And for the cruel man, who

Would tear out my living heart

I grow not thistle nor rocket

I cultivate the white rose.

(Cultivo una rosa blanca,

En Julio como en Enero,

Para el amigo sincero

Que me da su mano franca.

$Y$ para el cruel que me arranca

El corazón con que vivo,

Cardo ni oruga cultivo:

Cultivo la rosa blanca.)

$(16,117)$

The duality in the verses includes a contrast of months (one in summer and one in winter), a contrast between friend and enemy, and a contrast between plants that are harsh to both touch (thistle) and taste (rocket or arugula), and the gentle beauty of the rose. In Spanish, the poem is melodious, easy to memorize, and delivers a moral lesson. At the same time, it is more complex than it appears at a quick reading. "Una rosa blanca" in the first line means a single rose, but in Spanish "la rosa blanca" in the last line means roses in general, not just one, and reflects the message of extended compassion, which is at the heart of the poem. In line 7 Martí uses the world oruga, which means a strong-tasting salad green but also means caterpillar. Over time, many who are unfamiliar with the botanical meaning of oruga, which is what Martí wrote, have substituted the word ortiga (nettle) which occludes the contrast between touch and taste. Regrettably, numerous versions of the poem now use the word ortiga rather than oruga and thus miss part of the poem's meaning.

The poems in Simple Verses are rhymed, eight-syllable lines, a verse form in Spanish that is commonly found in popular poetic expressions, from ballads to the narrative songs known in Spanish as corridos. The verses are a natural format for recitation and music, and it is through music that the poems achieved worldwide fame. The journey from printed page to song began in 1940s Havana when a talented musician named Julián Orbón combined selected verses from Simple Verses with a popular Cuban melody called Guajira Guantanamera. One of Orbón's students, Héctor Angulo, introduced the song to American folklore singer Pete Seeger in 1961, at a summer camp in the Catskills, and Seeger made the song part of his repertoire, singing in Spanish but introducing and giving it visibility in English. As Seeger states of Guantanamera in Where Have All the Flowers Gone, "Martî's philosophic verses have ennobled the old melody ... I've sung it in 35 countries on four continents; it rings true in every one" (Seeger 2009, 128). The melody, paired with Martís verses, also spread through association with Martîs ideals and other writings and because of solidarity between Cuba and the former Soviet Union and Eastern bloc countries. Cuba's medical and aid personnel working abroad in Africa and Latin America have shared the song and encouraged its dissemination, and singers like Celia Cruz, Wyclef Jean, and Los Lobos expanded the appeal to audiences with a wide variety of musical preferences. Some versions stray far from Martís lines and have only an ephemeral connection to the poet. 
Nonetheless, the poetry's worldwide popularity is real; lines from Simple Verses, whether through song or though interest in Martí as a champion of popular causes, circulate in translation in an astonishing number of languages, including most Western European and Eastern European languages, Russian, Japanese, Chinese, Hebrew, Hindi, Welsh, Tagalog, Guaraní (an indigenous language in Paraguay), and Tzotzil Maya. In addition, people around the globe sing the poetry in Spanish. Cuban health professionals working in Africa have described children's groups as welcoming them with verses from Guantanamera.

An unfortunate outcome of the popular interest in Martí and Guajira Guantanamera is that misinformation and distortions abound, especially on the internet, but also in print books and articles. One false impression is that the song is from a poem rather than from selected verses from a specific book of poems, and some sources claim that Martí wrote a poem called "Guantanamera." Another distortion is the notion that the Guantanamera with Martîs lyrics is about a girl from Guantánamo, a confusion that arises from the fact that the word guajira can mean a peasant or country girl but is also a musical genre. In addition, garbled versions of the poems are widespread, and mistakes have been magnified through the internet. Fortunately, a fully digitized version of Simple Verses (Versos Sencillos) from the original text, just as Martí published it in 1891, is available online in the Romero Collection of the Library at the University of Florida in Gainesville, and thus provides an accessible and reliable source for all.

\section{"Our America": A Postcolonial Vision for the Americas}

Martî's vision for the future of the Americas is a frequent topic in his writing but, because of its masterful treatment of the subject, one essay has come to represent Martî's thinking on hemispheric relations. "Our America" is now widely read in fields beyond Spanish and Latin American literature, including United States literature, Latino studies, and Latin American studies, and is available in at least five different versions in English. Esther Allen's translation in Selected Writings (Martí 2002) is faithful to style and intent, successfully captures nuances linked to historical contexts, and is a widely accessible choice.

"Our America" was published in New York on 1 January 1891, and appeared at the end of the month in the Mexican newspaper El Partido Liberal (The liberal party). The essay is a literary masterpiece, replete with fresh metaphors, surprising similes, and complex images. It is also a sweeping view of Latin American cultures since independence and is full of historical allusions that can be difficult to interpret. Although it was sent to newspapers, it is not a chronicle, and as Roberto Fernández Retamar aptly notes, it is "both essay and poem" (Fernández Retamar 2002, 21). Its themes include nation building, cultural identity, race relations, and the specter of US domination in the hemisphere.

The essay begins with a call to the citizenry of Spanish American countries to awaken to the danger of the seven-league giant who threatens the hemisphere. Then Martí extols the "weapons of the mind," claiming that "trenches of ideas are stronger than trenches of stone and that no ship's prow can cleave a cloud of ideas" $(6,15)$. Martís weapons are his ideas for the future of a continent framed by shared suffering: conquest by Spain, centuries of colonial rule, turbulent wars of independence, and failure to achieve cultural independence. Martîs remedies for countries that had turned to the United States and France for political 
guidance and cultural identification after the break from Spain are to look inward and to include all citizens. In elaborate, elegant descriptions, Martí punctures the prestige of the ruling elites, while calling for the participation of Native Americans and African Americans in the hemisphere's future. In powerful declarations, he admonishes those who would scorn the indigenous heritage and disparage the descendants of Africa. Martí symbolizes the insidious problems faced by Spanish America after independence as a lurking tiger. The tiger lies in wait, ready for a chance to strike, as the republics enter a new era. Martí paints the dangers: a persistent colonial mindset, the obstacles to ending oppressive patterns of the past, the strife caused by internal struggles, and ever-present threats from abroad. In Martîs "Our America," the new societies must create rather than copy, replace foreign influence with native elements, and unite disparate factions. Near the end of the essay Martí emphasizes the urgency for Spanish America to stand united before the ominous threat from the North.

One of the signal contributions of "Our America" is its prophetic perspective on race and ethnicity. In recounting important moments of Spanish American history, Martí gives credit to the role of Indian populations in the struggle for independence and highlights the integrity of Benito Juárez, a Zapotec Indian from Oaxaca who became Mexico's president and champion of reform. In a series of pronouncements, he states that to spread hatred and conflict among races is to sin against humanity, that, in fact, there can be no hatred between races because there are no races, and that those in the Americas should appreciate the Greeks of the New World, i.e. Aztecs, Incas, and Mayas, rather than the Greeks of European antiquity. In highly distinctive language, the author of "Our America" refers to the supposed lethargy of Indians as resulting from an imposed stagnation because the Spanish conquest froze indigenous communities in place. He calls for those communities to be unfrozen and signals that Native Americans are essential to the future of Spanish America. In the essay, Martí also challenges the argument promoted by Argentine Domingo Faustino Sarmiento in Civilización y barbarie (Civilization and barbarism), that civilization was represented by cities, by learning, and by Europeans, and that barbarism was exemplified by the mixed-race gaucho and the inhabitants of Argentina's vast plains and rural outposts. Martî's belief that "the contest is not between civilization and barbarism but between false erudition and nature" $(6,17)$ includes a call for educated and uneducated citizens of Spanish America to work together in governing. Nonetheless, Martí clearly puts emphasis on the natural man and on native rather than imported elements for the creation of effective postcolonial nations.

"Our America" includes aphorisms that can stand alone as moral markers but also serve as important summary points in the essay. For example: "Government must be born of the country itself" $(6,17)$; "To be a governor in a new country means to be a creator" $(6,17)$; "To know is to resolve" $(6,18)$; and "To think is to serve" $(6,22)$. The concise statements reflect Martîs idealistic postcolonial vision for Spanish America: societies free of racial animosity, embracing the cultural identity of all, including African Americans and Native Americans, and looking to knowledge as a means of problem solving. At its close, "Our America" returns to the note of caution and challenge that opened the essay. Employing imagery linked to the indigenous past, Martí calls on Spanish Americans to stand united as they confront the dangerous disdain of the "blond" nation to the north. 
From essay to poetry, and from political messaging to personal sentiment, Martí is unique for his mixture of "vast information and constant originality" (Fernández Retamar, 2002 , 23). He was profound yet prolific and one result of his prodigious publishing is that we are still finding information about the extent of his influence. Articles that appeared in Spanish-language magazines in New York and newspapers throughout Latin America continue to be discovered. In 2015 and 2016 Martí researcher Jorge Camacho published a series of three books with writings not found in Martî's complete works (Fountain 2016). Through meticulous searching, Camacho found Martí essays and notes in newspapers in Panama and Mexico and in a Berlin archive that housed the Spanish-language journal El Economista Americano (The American economist) to which Martí contributed. As Camacho's discoveries reveal, knowledge about José Martí continues to grow and his work continues to attract scholarly attention around the globe. The world still has much to learn and appreciate about the life and impact of the sincere man born where palm trees grow.

SEE ALSO: Introduction to World Literature 1920 to the Early Twenty-First Century; From Decolonization to Decoloniality

\section{Note}

1 All quotes from Martîs Obras completas (Complete works) 1963-1973 (28 vols.) are indicated in the text by volume and page number. All translations are mine.

\section{REFERENCES}

Fernández Retamar, Roberto. 2002. "About My Writing on Martîs Work.” World Literature Today, 76 (3/4): 17-23.

Fountain, Anne. 2016. Reviews of three books by Jorge Camacho with newly discovered works by José Martí. The Latin Americanist, 60 (4): 582-586.

Martí, José. 1963-1973. Obras completas. 28 vols. Havana: Editorial Nacional de Cuba. Volume 28 of the Obras completas (New materials) was published by the Instituto Cubano del Libro.
Twenty-six of the volumes contain Martís works. Volume 26 is the index and volume 27 is a comprehensive table of contents.

Martí, José. 2002. Selected Writings, edited and translated by Esther Allen, introduced by Roberto González Echevarría. New York: Penguin.

Seeger, Pete. 2009. Where Have All the Flowers Gone, rev. edn., edited by Michael Miller and Sarah A. Elisabeth. Bethlehem, PA: Sing Out Corporation.

\section{FURTHER READING}

Fountain, Anne. 2014. José Martí, the United States, and Race. Gainesville: University Press of Florida.

Kirk, John M. 1983. José Martí, Mentor of the Cuban Nation. Tampa: University Presses of Florida.
Martí, José. 2000-2015. Obras completas: Edición Crítica, vols. 1-26. Havana: Centro de Estudios Martianos. Additional volumes are in progress. Available online at http://www. josemarti.cu/edicion-critica-obras-completas/, accessed October 2018. 
Martí, José. 2005. Versos Sencillos: A Dual Language Edition, introduction and translation by Anne Fountain, foreword by Pete Seeger. Jefferson, NC: McFarland \& Company.

Montero, Oscar. 2004. José Martí: An Introduction. New York: Palgrave Macmillan.

Rodríguez-Luis, Julio, ed. and intro. 1999. Re-Reading José Martí (1853-1895). Albany: State University of New York Press.

Rotker, Susana. 2000. The American Chronicles of José Martí, translated by Jennifer French and
Katherine Semler. Hanover, NH: University Press of New England.

Spangler, Ryan Anthony, and Georg Michael Schwarzmann, eds. 2017. Syncing the Americas: José Martí and the Shaping of National Identity. Lewisburg, PA: Bucknell University Press.

Vitier, Cintio. 2004. Vida y Obra del Apóstol Jose Martí. Havana: Centro de Estudios Martianos. 